\section{Calendar of Nature Topics}

\section{Most Northerly Position of the Doldrums}

The circulation of the air over the tropical and sub-tropical parts of the Atlantic and Pacific Oceans comprises the north-east and south-east trade winds, and a region near the equator of calms and light variable winds, termed the 'doldrums'. The simplified explanation usually given for this circulation is that the heating effect of the sun being greatest near the equator, the warmed air rises there and is replaced by cooler air flowing in from each side; the latter, deviated towards the west by the earth's rotation, forms the trade winds. In the northern summer the greatest heating occurs to the north of the equator and the whole circulation tends to move northward, but the air takes its temperature mainly from the sea, and owing to the sluggishness with which great volumes of water respond to seasonal changes of temperature, the movement of the circulation lags behind that of the sun, and the doldrums do not reach their most northerly position until early in September. For the same reason, the most southerly position is not reached until March.

\section{British Foxes}

An early clearing of the fields as was possible under harvest conditions in England this year, enabled the September cub-hunting to commence somewhat earijer thas usual. From the fox-hunter's point of view, cub-hunting is necessary to reduce the abundance of foxes in certain areas, for too many foxes, rather than too few, spoil sport when fox-hunting commences in full in November. It has generally been stated that the British fox, Vulpes vulgaris, like the pheasant, and the capercaillie, would have become extinct but for its preservation in the interests of sport. The average fox stands about fourteen inches at the withers and averages some three feet in length, with up to $17 \mathrm{lb}$. for a dog and $14 \mathrm{lb}$. weight a vixen; but some large specimens are on record. In the Zoologist, 1849, $J$. Duff recorded a Durham specimen weighing $70 \mathrm{lb}$., measuring $4 \mathrm{ft}$. $9 \mathrm{in}$. from tip to tip, and the height at the shoulder $1 \mathrm{ft} .10 \frac{1}{2} \mathrm{in}$. In all probability, the $70 \mathrm{lb}$. is a mistake for $17 \mathrm{lb}$. in Duff's record. E. A. Vaughan (Field, Feb. 8, 1913) recorded one dug out in Dorsetshire with the fox and the bag it was weighed in totalling $25 \mathrm{lb}$., and in the following issue, F. Gooding, huntsman to the Monmouthshire Hunt, recorded a dog fox of $24 \mathrm{lb}$. F. C. W. Rushworth (Field, March 4, 1916) recorded a fox of $28 \mathrm{lb}$. $14 \mathrm{oz}$ killed near Keighley, Yorkshire. Pure white foxes have occasionally been recorded and Millais states that pied ones are not rare. A black fox with a white tag was seen several times in Leicestershire in 1923 but not killed, and a black fox has occurred in the New Forest (Zoologist, pp. 17, 97 ; 1890).

\section{Icelandic Ducks begin to reach Britain}

Although it is probable that some of the Icelandic passerine birds may already have arrived in Britain, and although the only tufted duck. over recovered with an Iceland ring was shot in Cheshire in August, it is in mid-Septersber that the regular southward movement of these northern nesting ducks begins, as shown by the results of P. Skovgaard's ringing from 1925 until 1929 (Proc. Seventh Intern, Ornith. Cong, Amsterdam, 1931, p. 392). Amongst them the wigeon leads, and of four individuals recovered in September, three have been found in Scotland. Indeed it would appear that the majority of Iceland wigeon, on their first migration, winter in Scotland and Ireland, although older birds have generally been found farther south, even exceptionally in the north of Italy.

In another respect the dispersal of wigeon from Iceland is peculiar, for of the 29 individuals recovered (out of 294 ringed) four have occurred on the eastern seaboard of North America. As a rule, however, duck migration from Iceland is in a south-easterly direction to or through the British Isles, to Holland, the basin of the Rhine, and even to the Mediterranean Sea. For example, of 125 marked teal, eleven have been recovered, all on the line of route indicated; and of 23 golden plover recovered out of 341 ringed, not one has occurred without the boundaries of the south-eastern route.

\section{Unwelcome Gifts to Japan}

About 1900, the United States presented (inadvertently) the pea-weevil (Bruchus pisorum) to Japan, and in some ten years it had become distributed throughout the whole country. Twenty years later, Europe, having already sent samples of her beanweevil (Bruchus rufimanus) to Now Jersey in 1870 and to the Chicago Exposition in 1893, contributed this additional pest to Japan either direct or by way of the United States. The invasion may be a serious one, for Japan in 1930 cultivated 41, I90 hectares of broad beans, yielding a crop of 859,735 hectolitres. Accordingly Akira Kamito, of the Ministry of Agriculture at Tokyo, has been studying the habits of the beetle in Japan (Proc. Imp. Acad, Tokyo, 9, 137; 1933). September marks the close of its larval stages for the year ; for although only one generation seems to be reared each year, it spreads over many months, from the egg-laying of late April to mid-June to the last of the pupæ from which the adults emerge in October. The adults hibernate through the winter, reduced to a state of inactivity below $10^{\circ} \mathrm{C}$., and showing slight activity when the temperature rises above $10^{\circ}$ and moderate activity above $15^{\circ}$. In the state of hibernation, sheltered amongst stored beans, it survives for from seven to more than nine months, a viability very different from that of the active insect of summer, which lives for an average of only 34 days when supplied with abundance of food, and for 15 days without it.

\section{Catch Cropping}

One of the aims of arable farming is to produce the maximum amount of dry matter per acre suitable for direct sale or for feeding to livestock. An early season, such as the present one in England, enables a catch crop to be hurried in after harvest with the best prospect of success, provided that there is sufficient moisture left in the land for germination. Stubble turnips, Italian rye grass, rye, tares, or Trifolium can all make useful growth and provide good food for the following April, a time when fresh green food is most acceptable, as the pastures will not yet be fit to stock. Every day in August and September counts, and rapid preliminary cultivations are essential. If not required for feeding, these crops make green manures, and by covering the land in the winter they will have immobilised much of the nitrate which would otherwise have been washed out. They also contribute a supply 
of organic matter to the soil. Given clean land in a high state of fertility, and the means of conducting tillage operations at speed, catch cropping is a practicable method of using the growing season to the best advantage. This year winter oats and barleys were cut in the third week of July in many districts of England, presenting excellent opportunity for catch cropping.

\section{Societies and Academies}

\section{DUBLIN}

Royal Dublin Society, July 27. G. Cruess-CallaGHAN and M. J. GORMAN : Characteristics of Bacterium violaceum, Schröter, and some allied species of violet bacteria. Cultures of violet bacteria isolated from water samples appeared to be different from species previously described, but a comparative study of these cultures, and of as many as could be obtained from laboratories and collections elsewhere, led the authors to conclude that all those examined could, notwithstanding numerous differences among them, be regarded as strains belonging to three specific groups, namely, B. violaceum, Schröter, B. janthinum, Zopf, and $B$. amethystinum, Eisenberg.

\section{PARIS}

Academy of Sciences, July 24 (C.R., 197, 285-364). Gabriel Bertrand and L. SilberstenN: The sulphur and phosphorus in the various parts of the wheat grain. The fact that earlier analyses have usually been carried out on the ash instead of the wheat has led to too low a figure being accepted for sulphur. The ratio of sulphur to phosphorus varies from 0.09 in the bran to $I .039$ in flour. $R$. Fosse and A. BRunex: The presence of allantoic acid in fungi. The examination of more than twenty varioties of fungi showed allantoic acid in proportion between 0.14 and $6.72 \mathrm{gm}$. per $\mathrm{kgm}$. of dry plarit. P. RACHEVSKY : A characteristic criterion of conformal representations. JULES SIRE : The problem of Dirichlet, the potential function and the ensemble of irregular points. MaURICE GEvRey: Some questions concerning the elliptic and parabolic types. Use of the peripheral or spatial mediation. Unicity of solutions of systems of equations. AURÉLIAN DoNCESCU : The determination of the flame temperatures during expansion in internal combustion motors. The method used is based on that proposed by Féry in 1903 for the optical determination of the temperatures of non-luminous flames. Experiments with three different fuels are recorded as curves. A. Przeborski : The forces depending on accelerations. HADAMARD : Remarks on the preceding note. CH. RACINE : A class of solutions of the gravitation equations of Einstein. L. GoldSTEIN : The theory of complex photoelectric effects. Jean Guastalla : The equation of state of monomolecular films and comparison with the experimental results. P. BrQUARD: The absorption coefficients of ultra-sounds by different liquids. LEON GRILLET : The variation of the intensity of the radiations emitted by a quartz mercury vapour lamp during the period of lighting up. Measurements of the intensities of the rays emitted by two arcs, one stable after running for some time, the other just started. E. BAUER, M. MAGAT and A. DA SIIVErRA : The Raman spectrum of calcium nitrate. Previous work by the authors and by Grassmann has shown that the Raman line 720 of the nitrate ion is doubled in very concentrated solutions of certain nitrates. Further experiments are described which disprove the hypothosis of Grassmann, that the effect is due to the presence of undissociated molecules of ealcium nitrate. PaUL SolemLlet : The calculation of the amount of polarisation of radiations emitted by resonance. GRINBERG : Emissions of positive electrons by the $\gamma$-radiation of $\mathrm{Ra}(\mathrm{B}+\mathrm{C})$. G. Mano: The slowing down of the $\alpha$-rays. Comparison between theory and experiment. M. Briand, P. Dumanois and P. LaffrtTe : The influence of temperature on the limits of inflammability of some combustible vapours. Data are given for the vapours of benzene, toluene, cyclohexane and cyclohexene for temperatures between $100^{\circ} \mathrm{C}$. and $250^{\circ} \mathrm{C}$. T. MounaJED : The volatility coefficient of hydrochloric acid in anhydrous ether. RAYMOND Амгот: The adsorption by carbon of some phenols and polyphenols in aqueous solution. Mur.t. B. GREDY : The acetylene linkage. Study of a series of 2-acetylenic hydrocarbons. Raman spectra of four hydrocarbons R.C:C.CH ${ }_{3}$, where $\mathrm{R}$ is methyl, ethyl, propyl or butyl. M. Pretrre : The influence of active nitrogen on certain oxidation reactions. The oxidation of carbon monoxide is accelerated by active nitrogen, and the temperature of inflammation is lowered. Pikrre Thomas and Mlle. C. Kalman: The action of various sugars on the reaction of solutions on sodium molybdate. A. BOUCHONNET, MME. Trombe and Mlle. Petitpas: The nitration of cellulose. The use of 99.9 per cent nitric acid in the presence of mineral salts (ammonium nitrate, potassium nitrate) gives nitrocelluloses containing up to 13.87 per cent nitrogen. R. LEvaILLANT: The preparation of some ether salts of chlorsulphonic acid or of sulphurous acid. P. RUMPF : A new colour reaction of aldehydes. The reagent is a solution of rosaniline hydrochloride in anhydrous formic acid: the colour changes are followed with the spectroscope. P. DUQUÉNOIS : The distinction between trivalent and pentavalent antimony by the formation of antipyrine iodostibnate. The reagent of Caille and Viel (antipyrine dissolved with potassium iodide) gives a golden yellow precipitate with antimonous salts, and with antimonic salts a brick-red precipitate. JACQUES FromaGET : The presence of the Gigantopteris nicotincefolice flora in Haut-Laos and the stratigraphy of the Indosinides. MMr. Y. LABROUSTE : The periodic components of Love's waves. Mule. A. Dusseat : The sporogenesis of the hybrid Triticum haplodurum resulting from the crossing of two Triticum vulgare. G. PeTrT : A blind fish found in fresh water in a cavern in Madagascar : Typhieotris madagascariensis. A. GRUVEL: The distribution of some species of molluses in the lagoons of Lake Timsah (Suez Canal). R. BonNET: The validity in the Pœecilotherms of the TerroineSorg-Matter law on the magnitude of the endogenous nitrogen expenditure. Georges BourGUIGNON: Vestibular triple chronaxy. B. TrouveLOT, LACOTTE, DUSSY and THÉNARD : The elementary qualities of the plants supplying Leptinotarsa decem. lineata with food and their influence on the behaviour of the insect. Augusin Boutaric, Maurice Pietirie and Mlue. Madeletne Roy: The physico-chemical study of the flocculation of serum albumen by resorcinol. LÉON VELLUZ : The neutralisation of the diphtheric toxin by some heterocyelic molecules. The toxins of tetanus and diphtheria behave differently as regards their neutralisation by organic 